\title{
Guestworkers in Europe: A Resurrection?
}

Stephen Castles

International Migration Institute, James Martin 21st Century School, University of Oxford

Around 1974, most Western European countries abandoned migrant labor recruitment, and introduced restrictive entry rules. Today, policymakers are reexamining temporary migrant worker programs. This article examines demographic, economic, and social pressures for labor recruitment, discusses temporary migrant worker programs in Germany and the United Kingdom, and examines the European Commission's 2005 Policy Plan for Legal Migration. Current approaches differ significantly from the past and there is no question of a general return to labor recruitment policies. However, today's policies do share some common features with past guestworker programs, and may lead to negative social outcomes in both receiving and sending countries.

Twenty years ago, $I M R$ published my article entitled "The Guest-Worker in Western Europe: An Obituary" (Castles, 1986). It examined the recruitment of foreign workers by Western European countries after 1945, the reasons for stopping recruitment in 1973-1974, and the long-term consequences for Western European societies. Today, employers, politicians, and European Commission (EC) officials are considering a return to policies of systematic admission of migrant workers. Temporary or seasonal migrant worker programs have already been introduced in several Western European countries (OECD, 2005:103), while Southern European countries have used large-scale legalization programs to turn undocumented migrants into regular workers (Reyneri, 2003). Now a European Union-wide approach to admission of migrant workers has been proposed (CEC, 2005a, 2005b).

Are we about to witness a "resurrection" of guestworker recruitment in new guises? That is the central question of this article. It will look first at past experiences of foreign worker recruitment, and then discuss what has changed since to put labor import back on the policy agenda. Then the article will discuss experiences of temporary migrant worker programs (TMWPs) in certain European countries, and go on to look at the EC's recent Policy Plan. It will become evident that the current approaches differ significantly from the guestworker programs of the past with regard to differentiation between highly skilled and lower-skilled workers; the extent and duration of TMWPs; and the claimed intention of linking migration to the development of countries of 
origin. Thus there is no question of a general return to guestworker policies. However, I will argue that some current approaches do share common features with past guestworker programs, especially through discriminatory rules that deny rights to migrant workers. They may lead to negative social outcomes in both receiving and sending countries. ${ }^{1}$

\section{THE RISE AND FALL OF THE WESTERN EUROPEAN GUESTWORKER SYSTEM}

By the mid-1980s most observers believed that large-scale labor import to Europe had been caused by exceptional conditions, which would never be repeated. Between 1945 and the early 1970s, all the fast-growing industrial economies of Western Europe had imported labor, especially for lower-skilled jobs. In some cases (the United Kingdom, the Netherlands, France), many of the workers were from former colonies and had citizenship rights. In other countries migrants entered spontaneously and were then regularized. However, all the Western European countries tried systematic recruitment of temporary migrant workers at some point. The United Kingdom, France, Switzerland, and Belgium pioneered labor recruitment in the 1940s, while Germany, the Netherlands, and Austria followed later. Germany learned from earlier experiences and its guestworker system was based on a high level of state involvement. The idea was to ensure "rotation" by recruiting workers for a limited period, restricting their rights, and minimizing family reunion. Migrants were expected to accept relatively poor wages and conditions, make little demand on social infrastructure, and not get involved in labor struggles (Castles, 1986). Germany, like other Western European states, was trying to import labor but not people.

However, guestworker systems had limitations. In several countries, official recruitment systems had broken down by the 1960s, allowing unregulated entry and increased family reunion. Even in Germany, by 1969 only 44 percent of new foreign workers were officially recruited, with others applying at German consulates on the basis of individual job offers (Castles and Kosack, 1973:41-42). This was often a form of family reunion, since workers already

${ }^{1} \mathrm{An}$ earlier version of this article was the basis of a keynote address at the conference Fortress Europe? Effects and Consequences of Labour Migration, held by the Heinrich Böll Foundation in Hamburg, February 16-17, 2006. I thank the participants for their comments. I also thank the following for valuable criticism and suggestions: Joaquín Arango (Universidad Complutense, Madrid), Mark J. Miller (University of Delaware), and Martin Ruhs, Oliver Bakewell, and Hein de Haas (all University of Oxford). 
in Germany could get their employers to request their husband or wife by name. Children were often brought in as "visitors," while others were born in Germany. Undocumented entry was also increasing, with authorities sometimes tacitly regularizing migrants once they had jobs.

Many economists saw labor import as a key element in Western Europe's long economic boom (1945-1975) (e.g., Kindleberger, 1967). Yet in 1973, the German government suddenly stopped migrant entry, and most Western European governments followed by 1974 . The ostensible reason was the "Oil Crisis," seen as the onset of a period of economic stagnation and high unemployment. In fact, more fundamental factors were at work. Many industries were becoming dependent on migrant labor. Temporary workers were being recruited to meet permanent labor demand, and the "rotation" principle was breaking down. As migrant families grew, they needed family housing, schools, medical care, and social facilities. Migrant workers joined trade unions and participated in a wave of labor militancy in the early 1970s. Migrant labor was ceasing to be a low-cost option, and its social and cultural consequences were becoming evident. The theory of the guestworker system was that by stopping recruitment most migrants would leave fairly soon. In fact, many did, but others stayed. Family reunion speeded up, and settlement and ethnic minority formation became obvious to everyone (except some political leaders: it was not until 1998 that mainstream German political parties were willing to admit that Germany was a country of immigration).

Why did many migrant workers turn into permanent settlers? First, migrants' objectives were linked to the life cycle: young single workers originally intended to stay for a few years, but as they grew older and established families, their plans changed. Second, the recession was much worse in Turkey and North Africa than in Europe, so there were economic incentives to stay. Third, migrant workers had been partially integrated into welfare systems: entitlements to unemployment benefits, education, and social services made it worth staying despite worsening employment prospects. Fourth, in liberaldemocratic societies, governments could not simply expel legally resident foreigners: the courts protected their rights to secure residence status and to live with their families. Finally, a coalition of pro-immigrant forces, embracing trade unions, churches, and civil rights organizations, influenced policies through their links with social-democratic and liberal parties.

Now another element of the guestworker system became significant: it had been based on the inferiority and the separation of the foreigner. Western European societies did not integrate immigrants as equals, but as economically disadvantaged and racially discriminated minorities. As a result, immigrants 
tended to settle in specific neighborhoods, marked by inferior housing and infrastructure. Ethnic enterprises and religious, cultural, and social associations developed in these areas. Thus the inherent contradictions of the guestworker system led to today's ethnically diverse but socially divided European societies (Schierup, Hansen, and Castles, 2006). Since the 1980s, Europeans have become increasingly concerned about trends affecting ethnic minorities such as social exclusion, labor market segmentation, residential segregation, and high unemployment. Manifestations of conflict have included extreme-right movements, institutional racism, and minority youth riots (most recently in France in autumn 2005). This has led to a widespread belief that temporary labor recruitment should be avoided since it could have unpredictable social impacts.

\section{WHAT HAS CHANGED SINCE?}

The early 1990s saw an upsurge of migration to Western Europe. Newcomers included war refugees from former Yugoslavia; asylum seekers from the former Soviet Union, the Middle East, Africa, Asia, and Latin America; and new labor migrants - highly skilled and low-skilled, regular and irregular. The reaction of European policymakers was to tighten up national immigration restrictions and to increase European cooperation on border control. An important reason for this restrictiveness was the fear that temporary migrants might again turn into new ethnic minorities. But there was another reason. New techniques of communication, management, and control were making it profitable to shift mass production activities to countries with lower wages and more restricted worker rights. European governments therefore believed that low-skilled migrant workers would not be needed in Western Europe in the foreseeable future. Restrictive labor migration policies were maintained through the 1990s, despite the obvious fact that low-skilled workers were coming in as irregular migrants, family members, or asylum seekers. Moreover, Southern European countries that had been major sources of migrant workers in the past now became important immigration areas.

In recent years there has been a gradual shift in official views. An important milestone was the 2001 Süssmuth Commission Report (Süssmuth, 2001), which argued that Germany had long since become an immigration country and would need to rely on labor migration to fill both skilled and less-skilled jobs in the future. In Britain, after nearly 30 years without any serious economic analysis of migration, the Home Office published a report that highlighted the potential benefits of labor migration (Glover et al., 2001). European 
economists (Straubhaar and Zimmermann, 1992; Dustmann and Glitz, 2005) and governments began to participate in a debate on costs and benefits of migration that had already been under way in the USA, Canada, and Australia for many years.

What led to these change? A major economic factor was the realization that developed countries could not export all low-skilled work to low-wage countries. The manufacture of cars, computers, and clothing could be shifted to China, Brazil, or Malaysia, but the construction industry, hotels, restaurants, and hospitals had to be where their customers lived.

A major demographic factor was the realization that total fertility rates had fallen sharply. Eurostat projections show that the population of the EU25 2 as a whole is likely to fall by 1.5 percent from 457 million in 2004 to 450 million by 2050 . However, the decline will be much greater in Germany (9.6 percent), Italy (8.9 percent), and the ten mainly Eastern and Central European "Accession States," which joined the EU in 2004 (11.7 percent). More serious still is the decline in working age population (15-64): currently in the EU25, 67 percent of the population is of working age, compared with 16 percent of $65+$. By 2050, a working age population of 57 percent will have to support 30 percent aged 65+ (CEC, 2005a:Annex Tables 1 and 2). As the EC argues (CEC, 2005a:Section 1.2):

In the short to mid-term, labor immigration can ... positively contribute to tackling the effects of this demographic evolution and will prove crucial to satisfying current and future labor market needs and thus ensure economic sustainability and growth.

Other factors behind support for new labor immigration policies include:

- The informal economy: despite official calls to suppress this (CEC, 2005a:Section 1.1), there is strong evidence that the informal economy has grown in recent years, and is indeed an unintended consequence of official measures to secure a "flexible labor market" (Reyneri, 2001, 2003).

- Demographic shifts can also lead to social change. The proportion of children aged $0-14$ in the EU25 population is projected to fall from 16.4 percent in 2004 to 13.4 percent in 2050 (CEC, 2005a:Annex Table 2). If there are fewer young people, these may expect improved educational opportunities, and few of them are likely to be available for low-skilled jobs.

${ }^{2}$ The EU25 refers to the 25 Member States of the European Union following the accession of 10 new members in May 2004. 
- Globalization has been marked by growing inequality. "Today, high-income countries have per capita GDPs that are 66 times those of low-income countries and 14 times those of middle income countries" (GCIM, 2005:12). This inequality is a very powerful force driving migration. Developed countries are therefore under pressure to open up legal channels of migration that may be conducive to development of the South.

- Similarly, the efforts of northern countries to recruit highly skilled personnel from the South have led to fears that the "brain drain" would lead to shortages of key personnel in healthcare, education, management, and administration and thus hamper economic development. This too compels European governments to look for cooperative ways of managing migration.

- The other great disparity between Europe and many less-developed regions concerns the level of democracy and human rights. Many new entrants are refugees and asylum seekers; others are people with "mixed motivations." The realization that many migrants are fleeing both poverty and repression has strengthened calls for forms of migration management that address both economic and forced migration.

\section{THE REDISCOVERY OF TEMPORARY MIGRANT WORKER PROGRAMS IN DEMOCRATIC STATES}

In global perspective, TMWPs did not end with Europe's 1973-1974 recruitment ban. Capital investment and industrialization in the Gulf oil states and the Asian "tiger economies" led to large-scale labor migrations, often managed through contract labor systems (Abella, 1995; Skeldon, 2000; IOM, 2003). Typical of such systems were the strict rules designed to prevent longterm residence and family reunion. The governments concerned were aware of the Western European experience and were determined to prevent a repetition in their own countries. International migration scholars argue that TMWPs can succeed in less democratic states, which deny rights to foreign workers, restrict access to the legal system, and make draconian use of deportation. ${ }^{3}$ By

\footnotetext{
${ }^{3}$ Whether these countries can prevent settlement in the long run is not clear, since there do appear to be trends toward labor market dependency on migrants and increased family reunion in some Asian countries (Castles, 2003). Moreover, the strikes and demonstrations by migrant workers in Dubai in early 2006 showed the difficulty of permanently suppressing worker rights. But that is not the theme here.
} 
contrast, there is a widely held belief that TMWPs are unlikely to succeed in democracies, because of the existence of strong legal systems and international human rights instruments. Migrants - even those officially considered to be temporary - gain welfare entitlements and acquire civil and political rights. It is very hard for democratic countries to force former guestworkers to leave. This helps explain why some democratic labor-importing states - notably Japan and the USA - have not made much use of guestworker systems, but have instead tacitly tolerated undocumented migration (Castles, 2004; Martin, 2004).

However, in recent years there has been a tendency to advocate a return to TMWPs in democratic receiving countries. One reason is the perceived demand for migrant workers due to the economic and demographic factors outlined above. A second reason is the realization that border control alone will not fully prevent labor migration, but instead drives it underground. A third reason is the post-September 11, 2001, belief that undocumented migration is a security problem. If migration is going to take place anyway, politicians now think it better to control entrants to ensure that they do not pose a security threat. This was the thinking behind President Bush's January 2004 proposal for a US guestworker program (Migration Policy Institute, 2005). In the meantime, the Republican Party has forced through Congress a law calling for the construction of a wall along much of the border with Mexico. This in turn has evoked mass demonstrations by Hispanic workers and their supporters. The Republican Party is split on the issue.

A fourth reason for the renewed interest in TMWPs is the belief that appropriate policy settings could avoid the pitfalls of the past. This view is well summarized in a recent article, which argues that such programs can bring significant net benefits for receiving countries, migrants, and their countries of origin. However: "To achieve these net-benefits in practice will almost certainly require a high degree of government involvement and intervention in the labor market" (Ruhs, 2005). Ruhs maps out the measures that would be needed:

- The strict enforcement of immigration and employment laws, especially against employers who illegally employ migrants and /or violate minimum wage and employment regulations.

- The regulation of the cost at which migrants are made available to employers through, for example, the charging of monthly work permit fees for each migrant employed.

- The implementation of effective labor market tests, i.e., of mechanisms that create incentives for employers to recruit migrant workers only after all reasonable efforts have been made to recruit local workers. 
- The regulation or at least the monitoring of the migrant recruiting industry with an eye to controlling migrants' costs of migration.

- The protection of migrants' rights by making work permits portable within certain sectors or occupations after a certain period of time.

- Mixed incentive-enforcement measures to facilitate the return home of migrants whose temporary work permits have expired.

Ruhs argues that any temporary worker program will involve "some trade-off between the economic gains . . . and restrictions of some of the individual rights of migrants while employed abroad" (2005:14). He also notes that TMWPs "will always lead to pressures for permanent settlement of at least some of the migrants admitted as guestworkers" (2005:18), but believes that such pressures can be minimized through a mixture of enforcement measures and incentives to return home. Host countries may decide to allow the transfer of a certain number of temporary workers to permanent status, but this should not become an expectation for migrants at the time of recruitment. Ruhs's paper was written for the Global Commission on International Migration (GCIM) and appears to have had a significant impact, as the GCIM recommends that: "States and the private sector should consider the option of introducing carefully designed temporary migration programs" (2005:16). The GCIM Report notes the danger that TMWPs can lead to worker exploitation and unplanned permanent settlement, but argues that such outcomes can be prevented by appropriate policies (GCIM, 2005:17-18). In positive terms, the intention is to replace exploitative guestworker programs with mutually beneficial systems of voluntary circular migration. ${ }^{4}$

This positive view of TMWPs raises important questions. First, is it possible to achieve the high level of state control of temporary migration that Ruhs and the GCIM envisage? This is a crucial point: TMWPs can only succeed if governments take an active regulatory role. This would mean a reversal of neo-liberal approaches, which have led to a reduction in state involvement in European economies since the 1980s. It would also require employers to relinquish some of the profits obtained through poor wages and conditions for migrant workers. It seems more likely that employers would

${ }^{4}$ The term "circular migration" is used positively by the GCIM, but does not appear to be defined in its Report. Elsewhere, circular migration is linked to the idea that "if migrants feel that a decision to return home is not irreversible, they will be more likely to make such a decision." This can be achieved through "the introduction of flexible citizenship or residence rights." The idea is that migrants could then undertake repeated short periods of work abroad, increasing labor market flexibility and reducing permanent settlement (IDC, 2004:48). 
prefer to employ undocumented workers, rather than accept higher wage costs. A second question is of a more normative character: is it acceptable to trade off worker rights for economic gains? This seems problematic, as it could undermine parallel calls by GCIM for improved global governance of migration, through implementation of ILO and UN Conventions laying down worker rights. A third question is whether the mix of enforcement measures and incentives envisaged by Ruhs and the GCIM would actually prevent settlement of temporary workers. This would imply that the state has more capacity to override the sort of factors that led to settlement in Western Europe after 1973. Despite stricter immigration rules in recent years, there is no clear evidence that this is the case.

\section{RECENT EXPERIENCES OF TEMPORARY MIGRANT WORKER PROGRAMS}

There is currently a global trend toward more temporary labor migration, and repeated and circulatory migrations are becoming much more common. One way of encouraging this is through regional free movement agreements, as within the EU, but this seems to work well only if there is a commitment to long-run equalization of the economic levels of the participating countries. As Martin points out in another paper for GCIM, many governments prefer unilateral or bilateral temporary worker programs. However: "many and perhaps most of the world's migrant workers are outside legal admissions channels" (Martin, 2005). So the current situation is that international bodies like the GCIM favor multilateral solutions, governments favor bilateral or unilateral programs, and employers often prefer undocumented workers - and many governments seem to tacitly accept this. However, several European countries have set up programs to recruit, admit, or regularize migrant workers.

Most developed countries have special immigration rules for highly skilled workers. There is strong international competition for qualified and experienced specialists, especially in management, information and communications technology (ICT), and the health sector (Findlay, 1995). The USA, Australia, and Britain attract highly skilled personnel by offering them opportunities for family reunion and permanent settlement. By contrast, Germany's 2000 "Green Card” scheme for 20,000 ICT specialists did not allow family reunion and long-term residence (Green, 2004). The scheme was a failure, with only about 5,000 ICT workers taking it up. Germany's 2004 Zuwanderungsgesetz (Immigration Law) (Bundesministerium des Innern, 2004) was thus designed to facilitate entry of highly skilled personnel requested 
by employers. For the first time, such migrants could apply immediately for permanent residence.

In the long run, meeting demand for lower-skilled workers is likely to be equally important to Europe, and it is here that policy is least developed. Most states still reject the idea of legal entry provisions for low-skilled non-EU workers. One reason for this is the belief that future labor needs can be met from the labor surpluses of the ten Accession States which joined the EU in 2004 and of Bulgaria and Romania, which will join in 2007. Instead, schemes for temporary or seasonal entry of limited numbers to meet specific labor need have been established by Germany, the Netherlands, Norway, the United Kingdom, Ireland, Belgium, Sweden, Greece, Italy, and Spain (OECD, 2005; Plewa and Miller, 2005:103-105). It is not possible to review these schemes in detail here, so the account will focus on Germany and the United Kingdom.

Germany makes more systematic use of TMWPs than any other European country (Schierup et al., 2006:151-154). In the late 1980s, the combination of growing labor demand in Germany and relaxation of departure controls in Eastern European countries encouraged Poles, Czechs, and Hungarians to enter as "tourists" and spend short periods working in agriculture, building, or catering. The German authorities favored this migration, but preferred it to take place in a legal and organized way. They therefore introduced a number of foreign-worker programs (often referred to as "new guestworker programs") (Rudolph, 1996). The largest is the seasonal worker program, set up in 1991, which provides for bilateral agreements with Central and Eastern European countries to admit workers for up to three months in agriculture, building, or catering. In 2001 there were 278,000 seasonal workers, of whom 85 percent came from Poland, and the rest mainly from Romania, the Slovak Republic, Croatia, and Hungary (OECD, 2004:200). Recruitment is subject to "EU preference": seasonal workers may be employed only if no EU workers are available. Another program is for foreign "contract workers," employed by firms in their home country, who come to work in Germany for up to two years on specific projects, usually in construction. There were 47,000 such workers in 2001, nearly half of them from Poland (OECD, 2004:200). The workers remain employees of their homeland companies, and their wages and conditions represent a considerable reduction in real labor costs for the German firms. Smaller programs cover cross-border commuters from the Czech Republic and Poland, and short-term recruitment of nurses.

Transnational subcontracting arrangements within the European Union are a further way of providing flexible labor for the German building industry. Workers from countries with relatively low wages and social costs such as 
Portugal may be "posted" temporarily by their firm in Germany. More than 200,000 employees from other EU countries were working on German construction sites in 1999 (Hunger, 2000:189). A study of the Berlin building industry (Hunger and Thränhardt, 2001) explored the consequences. Following reunification and the move of the German government to Berlin, the city experienced an unprecedented building boom. Yet 25 percent of unemployed persons in Berlin were building workers by 1996. Employers preferred to take on cheaper contract workers or posted workers. This competition had adverse effects on unionized building workers, many of whom were long-term foreign residents of Berlin. As Hunger and Thränhardt point out, in the old German model of long-term employment, the workplace and the trade union were sites of interethnic communication and integration. The decline of the long-term employment model and its replacement with contract workers thus had negative effects on social integration and intergroup relations.

At the same time, trends toward the growth of small enterprises, deregulation, casualization, and contracting-out opened up the space for informal employment. Undocumented workers in Germany include illegal immigrants, but the majority are probably people who entered legally but who do not have (or have lost) permission to work. This includes asylum seekers awaiting a decision. Some workers in irregular employment are actually legally resident foreigners who cannot obtain regular work contracts (Wilpert and Laacher, 1999:53). It is impossible to say how many undocumented workers there are in Germany: Düvell notes estimates of between 0.5 and 1.1 million (2005: Table 2.1).

The United Kingdom has also set up programs to bring in both permanent and temporary workers. In conditions of high economic growth, there have been shortages of highly skilled personnel, while local workers are not available for many low-skilled jobs in agriculture, food processing, hotels and catering, and cleaning. Since 1997 the government has promoted economic migration to provide scarce skills and to increase the competitiveness of the UK economy (Clarke and Salt, 2003:564). The aim has been "managed migration" through a work permit system based mainly on employer demands - the Home Office prides itself on processing 90 percent of such applications within one day (Somerville, 2006:35). In 2004, 124,000 persons were admitted on work permits, of whom 82,700 were permit holders and 41,600 their dependents (Office for National Statistics, 2005). Two-thirds of immigrants are highly skilled, mainly working in managerial and professional occupations (LaytonHenry, 2004:319), especially in the fields of ICT, health, and education (Clarke and Salt, 2003:547). 
However, there was no similar effort to set up a general recruitment system for low-skilled migrants. Instead, the Home Office established a complex system of specialized work permits. These included (all figures below are from Office for National Statistics, 2005:Table 1.2):

- Working holiday-makers: originally people aged between 17 and 27 from Commonwealth countries, who could work for up to two years, but had no entitlement to welfare benefits nor to stay on afterwards. Young people from such countries as Australia, New Zealand, or Canada took on a range of jobs. In 2002, they numbered 41,700. In 2003, the age limit was raised to 30 , and visa holders were permitted to switch to the work permits scheme after one year. Entries under the scheme increased to 62,400 in 2004 .

- $\quad$ The Seasonal Agricultural Workers Scheme (SAWS) was set up to bring in young people from across Europe to work for up to three months in agriculture. The number of entrants was 17,000 in 2002, 21,000 in 2003, and 15,000 in 2004. Most SAWS migrants came from Poland, Ukraine, and the Baltic States. All these countries, except Ukraine, joined the EU in 2004.

- The Sector Based Scheme (SBS) was set up in 2003 to provide lower-skilled workers for food processing and hotels and catering, with an annual quota of 10,000 for each sector. Many in the hotels and catering quota were Bangladeshis, recruited by Asian restaurants. Workers were only allowed to come for one year, but it was impossible for them to recoup their high migration costs (fares, bribes to officials, etc.) in this period, so most stayed on illegally. The scheme was suspended in 2005 .

- Britain also admits migrants for domestic service - about 10,000 a year since 2001. A related category is au pairs (mainly young women who assist with childcare and housework): their number fell from 15,000 in 2003 to 5,600 in 2004 .

- A further source of short-term labor is overseas students, who are permitted to work up to 20 hours a week during term-time, and full-time in college holidays. In 2004, 294,000 students and 13,000 dependents were admitted. It is not clear how many entered the labor market, but it is known that many did.

These limited recruitment schemes have proved insufficient to meet the demand for low-skilled workers in the United Kingdom. As a result of policies of economic deregulation started in the Thatcher years and continued by 
the Labour Government since 1997, the British economy is very open to casual and informal work relationships, making it easy for employers to take on undocumented migrants and asylum seekers. The undocumented population is unknown, but estimates range from 50,000 to 500,000 (Düvell, 2005:Table 2.1). Government ministers and Home Office officials are aware of this, but seem to find this situation preferable to setting up adequate legal migration channels - which would encounter vocal opposition from the right-wing tabloid press.

In any case, the situation changed fundamentally in May 2004 with the accession to the EU of several countries that had been main sources of undocumented workers (Poland, Czech Republic, Latvia, Lithuania, and Estonia). The United Kingdom, unlike all other EU countries except Sweden and Ireland, did not introduce a waiting period for such workers, so they immediately became legal members of the workforce. There were 277,000 registrations of Accession State nationals as workers from May 2004 to September 2005 (Home Office, 2005).

In March 2006, the British Government published a White Paper announcing a comprehensive reform of the immigration system. The new points-based system is to be "focused primarily on bringing in migrants who are highly skilled or to do key jobs that cannot be filled from the domestic labor force or from the EU" (Home Office, 2006:1). Points will be awarded for "attributes" (such as educational qualifications, previous earnings, prospective earnings, and age) and "control factors" (which are concerned with preventing over-staying and irregular employment through a sponsorship system) (Home Office, 2006:16). The new system has five tiers: Tier 1 is for highly skilled individuals; Tier 2 for skilled workers with a UK job offer; Tier 3 for "limited numbers of low skilled workers needed to fill specific temporary labor shortages"; Tier 4 for students; and Tier 5 for youth mobility and temporary workers "for a limited period of time to satisfy primarily non-economic objectives" (Home Office, 2006:2). The White Paper makes it clear that low-skilled migration from outside the EU is to be phased out by 2010 .

The Home Office assumes that all future demand for low-skilled workers will be met through entries from Accession States, including Romania and Bulgaria after 2007 (Home Office, 2006:29-31). The success of the new system depends very much on whether this assumption is correct. In fact, projections show that Eastern and Central European countries will experience dramatic demographic decline in the future (CEC, 2005a:Annex Tables 1 and 2). Moreover, as their economies develop, they are likely to employ more of their domestic labor potential. It therefore seems probable that this labor 
source will only be sufficient for UK demand in the short to medium term (perhaps 5-10 years). After that, undocumented labor migration from outside the EU may well increase once more - or the British Government will have to change its entry system yet again.

What lessons do the German and British cases have for the perspectives of TMWPs in Europe? Germany's "new guestworker" programs are linked to the availability of migrant workers in neighboring countries who are willing to meet seasonal and temporary needs for labor. However, where these needs are not in fact temporary, undocumented work is also significant. The United Kingdom has concentrated on encouraging immigration of the highly skilled while opening only small "side-doors" for the low-skilled. Undocumented employment seems to play a major role in certain economic sectors. The response to EU enlargement has been to close even these side-doors. In both cases, it is clear that guestworker programs on the pre-1974 scale are not envisaged. TMWPs are only used for specific and limited purpose.

It is difficult to generalize from these two cases. In Southern Europe, guestworker-type programs have not played a significant role, since spontaneous entry followed by periodic regularization measures seems to have proved an effective way of channeling workers into economies marked by high levels of informal employment (Reyneri, 2003). The quota system introduced in Spain in 2002 to bring in migrants on short-term permits to meet specific labor-market needs was small in scale and seems to have been rather ineffective (OECD, 2005:104). Plewa and Miller (2005) draw attention to the way programs for temporary migration have been undermined by the possibility of achieving regularization and long-term residence. They argue that legalization of the type used extensively in Spain and Italy in recent years does give workers more rights, but may cause employers to replace the legalized workers with new undocumented migrants. In any case, legalization tends to lead to permanent settlement, because migrants are reluctant to give up their residence status, once they have obtained it. However, Arango argues that the idea of a guestworker system was never considered in Spain, and that initial one-year permits are renewable, allowing migrants to apply for permanent residence after 5 years. ${ }^{5}$ Similarly, according to Reyneri, recent research indicates that workers who have achieved regularization in Italy have on the whole managed to keep this status. ${ }^{6}$ Thus it might be argued that the Southern European model of

\footnotetext{
${ }^{5}$ Personal communication from Professor Arango, March 2006.

${ }^{6}$ Presentation by Professor Reyneri at the conference Fortress Europe? Effects and Consequences of Labour Migration, held by the Heinrich Böll Foundation in Hamburg, February 16-17, 2006.
} 
spontaneous entry and informal economy (King, Lazaridis, and Tsardanidis, 2000) has little need of TMWPs. Migrants may be less exposed to the constraints of guestworker programs, but they are highly vulnerable to changing government policies on entry and residence, exploitation in the labor market, and social exclusion (Reyneri, 2003).

Plewa and Miller (2005) provide some general insights into TMWPs in Europe. They find that recent guestworker programs have been much smaller than earlier ones. However, they argue that the policies have been essentially the same: the economic objectives of both receiving and sending countries are paramount, while workers have substandard social conditions and limited rights. The linking of work permits to specific employers, areas, or occupations has weakened the position of migrant workers. In addition, the frequent preference of employers for undocumented workers undermines temporary worker programs. Thus it appears that the new guestworker programs have the same flaws as earlier ones, and are unlikely to achieve their aims of meeting low-skilled labor demand and preventing settlement.

This limited nature of TMWPs in Europe is perhaps one reason why undocumented entry and employment have become so significant. Although accurate figures do not exist, experts put the total number of undocumented immigrants in the EU at between 4.1 and 7.3 million (Düvell, 2005:Table 2.1) - lower than the 11.5-12 million in the USA (Passel, 2006) but still very significant. In analytical terms, we may see TMWPs and systematic use of undocumented workers as alternatives. Although employers and policymakers are reluctant to admit it, they may well consider irregularity a better option in some cases, since it may avoid both economic and political costs. The social costs, on the other hand, are borne by both migrants and local workers.

\section{THE EUROPEAN COMMISSION'S 2005 GREEN PAPER AND POLICY PLAN}

\section{The "Road Map" for Migration}

The Green Paper on an EU Approach to Managing Economic Migration of January 2005 was part of the Commission's response to the Hague Program on migration policy adopted by the European Council in 2004. The Green Paper was designed to "launch a process of in-depth discussion ... on the most appropriate form of Community rules for admitting economic migrants and on the added value of adopting such a common framework." The Commission notes that the EU25's working age population will fall by 20 million between 2010 and 2030, which "will have a huge impact on overall economic growth, 
the functioning of the internal market and the competitiveness of EU enterprises" (CEC, 2005b:3). The Commission therefore argues that it is time to reconsider restrictive immigration approaches, especially because the absence of appropriate policies may lead to increased irregular flows. While recognizing that decisions on admission of economic migrants are the responsibility of Member State governments, the Commission advocates "transparent and more harmonized common rules and criteria at EU level for admitting economic migrants" (CEC, 2005b:4).

The Green Paper certainly did lead to the intended discussion, both through debate at a public hearing in June 2005 and through a flood of critical submissions by official agencies and nongovernmental organizations (e.g., Amnesty International, 2005; JCWI, 2005). The upshot of the discussion was the publication of the Commission's Policy Plan on Legal Migration in December 2005:

The Policy Plan defines a Road Map for the remaining period of the Hague Program (2006-2009) and lists the actions and legislative initiatives that the Commission intends to take, so as to pursue the coherent development of EU legal migration policy. (CEC, 2005a:3)

The Policy Plan argues that economic immigration responds to a "need scenario" in Member States, which are already experiencing substantial labor and skill shortages. These shortages are sure to get worse and concern "the full range of qualifications - from unskilled workers to academic professionals" (CEC, 2005a:4). On this basis one might expect a comprehensive plan for migration policy, embracing all skill levels. However, this is not what is to be found in the Policy Plan. Although the Green Paper had floated the idea of a "horizontal framework covering conditions of admission for all third-country nationals seeking entry into the labor market of the Member States," this was rejected by several Member State governments. Instead the Policy Plan proposes a "general framework directive" and four "specific instruments."

The general framework directive would be designed to "guarantee a common framework of rights for all third-country nationals in legal employment already admitted in a Member State, but not yet entitled to long-term residence" (CEC, 2005a:5). This could be linked to a "joint work/residence permit - held by the worker and containing the most advanced biometric identifiers," which in turn would be linked to the existence of a legal work contract. This might improve the security of residence of some existing migrants, and allow their mobility throughout the EU. However, it would not be relevant for new migrant workers. Moreover, existing migrants would apparently lose 
both their work and residence permits if the employer terminated their work contracts. This appears to reinforce migrant workers' vulnerability.

The four specific directives concern the following types of migrant workers (CEC, 2005a:6-8):

- Highly-skilled workers, for whom common special procedures for selection and admission as well as attractive conditions would be offered.

- Seasonal workers for agriculture, building, and catering, who would be allowed to come in for a certain number of months per year for 4-5 years. No possibility of transferring to permanent employment and residence is envisaged.

- Intracorporate transferees moving within international companies, who would be granted temporary residence.

- $\quad$ Remunerated trainees, who would be allowed temporary residence while on a recognized training course (which might include paid work) with EU firms.

The main emphasis in the Policy Plan is on attracting highly skilled workers, which fits in with the existing practice of many EU Member States. Such an emphasis can be problematic, if it leads to a "brain drain" of key workers and human capital from poor countries. Of course, many highly skilled workers circulate between developed countries, but there is growing concern about the emigration of key professionals, who may be important for the economic development and social well-being of origin countries in the South. This applies particularly to medical personnel. Between a quarter and a third of physicians in the United Kingdom, Canada, the USA, Australia, and New Zealand are foreign-trained. The major source regions are Africa, the Caribbean, South East Asia and South Asia. The British National Health Service had more than 30,000 nurses of foreign origin in 2002, and is heavily dependent on the recruitment of trained staff from Africa and Asia (Alkire and Chen, 2006:104-105). Ghana lost an estimated 61 percent of graduates of the main medical school, who qualified from 1986-1996 (Dovlo, 2006:118). The effects are even more problematic for Southern African countries like Malawi, which is struggling with the HIV-AIDS epidemic: according to the GCIM "it is estimated that there are currently more Malawian doctors practising in the northern English city of Manchester than in the whole of Malawi” (2005: 24).

However, what is most significant in the Policy Plan is not what is in it - but what is not. It adds up to a set of limited measures designed to encourage and harmonize types of labor import already encouraged by Member States. It 
completely fails to address one of the key long-term problems of EU labor markets, even though this problem is stressed in the Commission documents - the projected future demand for labor of all skill levels. Thus the Policy Plan will do nothing to address the growth of undocumented migration, and the high risks and exploitation that such migration brings for the workers concerned.

The Policy Plan also contains proposals to improve information resources for migrants and to improve the economic and social integration of immigrants already in the EU. It stresses the need to improve collaboration with "third countries" (i.e., countries of origin and transit) to develop "win-win opportunities" for both the migrants and the countries concerned. Identifying and addressing the negative effects of specific cases of brain drain is one aspect of this. But it is hard to know how seriously this will be taken in EU policy if it contradicts the central objective of attracting highly skilled migrants. Proposals for facilitating return migration and circular migration, for instance through long-term multi-entry visas, fit in with proposals made in recent studies on migration and development (IDC, 2004; GCIM, 2005).

\section{Open Questions on the Commission's Policy Plan}

The current debate on economic migration to the EU raises some important questions.

First, does the European Commission's Policy Plan offer an adequate and realistic "road-map" for meeting the EU's future labor needs? It appears to do so only for quite limited categories: highly skilled workers, seasonal workers for specific sectors, intracorporate transferees, and remunerated trainees. Here the Plan could bring about harmonization and possibly more intra-EU mobility. However, these are sectors already fairly effectively covered by Member State laws and policies. The potentially more important goal of creating legal channels for lowerskilled workers is left out of the Plan. The need for such workers is stated, but nothing is done to meet it. It seems that pressure of powerful Member States has forced the Commission to drop its original call for a comprehensive system of management of economic migration. These Member States hope that migrants from Accession States can fill the EU's future labor gaps. Limits on labor migration from Accession States imposed in 2004 will soon probably be dropped by most of the older EU countries. However, this hope seems misplaced, since Eastern and Central European countries face sharp demographic declines, and are likely to need their own labor resources. Even Turkish accession (which is uncertain to happen and is at least ten years away) would not meet long-term labor needs, in view of Turkey's declining fertility and rapid economic growth. 
Second, can temporary worker programs meet the future labor needs of the $E U$, if these are not temporary in nature, but rather the result of long-term shifts in demographic and economic structures? Analysis of the past European experience with guestworker programs exposes the inherent contradiction of such approaches. European (and most notably German, Dutch, Austrian, and Swiss) employers brought in workers on short-term permits, but the labor demand was not of a short-term nature. The official "rotation" policy failed, because employers wanted to retain experienced workers. EU projections of labor demand show that much of this is not short-term or temporary. With labor shortages across the board, employers will fight to retain workers, and there is no reason to think that current approaches will be any more sustainable than those of the past.

Third, what impacts might implementation of the Policy Plan have on the rights and social conditions of migrant workers? It might lead to some improvements in legal rights and intra-EU mobility for existing immigrants legally present in the EU. However, the Plan appears unlikely to do anything to improve the rights and conditions of future migrant workers. The relatively small numbers of legal low-skilled migrants will be treated as temporary workers with enforced rotation and no right to settle. The larger contingents of lower-skilled workers who come to Europe in response to strong demand for labor will have no choice but undocumented entry and irregular work. They will remain marginalized and exploited, at the mercy of people-smugglers and unscrupulous employers. The increased efforts at border enforcement will make entry even more risky than it is at present.

Fourth, will the Policy Plan lead to better collaboration with third countries, and hence to "win-win" outcomes for countries of origin and destination, as well as for the migrants themselves? The Plan does propose measures to limit harmful brain drain, but these measures are not outlined in detail and look very much like an afterthought. Ideas for linking migration to development, for instance through facilitating return and circular migration, and encouraging productive use of remittances, are worthy of support. But the implementation of such measures would require European countries to give up some of the advantages they gain from importing labor from the South. This is not spelled out in the Policy Plan, and it is not clear how such a shift would be achieved.

\section{CONCLUSIONS}

This article started with the question whether new approaches to labor migration in the EU and some of its Members States are tantamount to the 
"resurrection" of the guestworker system. The analysis shows that such a conclusion would be both simplistic and misleading. The policies of the 19451974 period were designed to import low-skilled guestworkers. Today, official policies in the EU (and indeed throughout the developed world) target the highly skilled, while less-skilled workers are admitted only in limited numbers through temporary and seasonal labor programs. The examination of policy trends in Germany, Britain, and the EU as a whole showed the ever-stronger emphasis on importing human capital while restricting the entry of lessqualified workers. Policies to meet labor shortages are designed as temporary and limited schemes for specific sectors. This approach seems short-sighted, since shortages of labor for lower-skilled occupations are already a permanent feature of European economies, and may well grow in the years ahead.

The European Commission argues convincingly that future labor needs will go right across the qualification spectrum, yet its Policy Plan fails to set up mechanisms for legal migration for the lower-skilled. On this basis one could argue that Europe's migration polices are even more misguided and hypocritical than they were before 1973. Europe's failure to face up to the realities of the situation leads to the great hypocrisy of modern migration policy (one shared by the USA and Japan): the systematic use of undocumented migrant workers, who are denied many of the rights laid down in the human rights instruments and labor conventions endorsed by these same countries. Building walls (between the USA and Mexico) and increasing naval patrols (between the EU and Africa) increases the death rate and the smugglers' profits, but does not solve the problem. ${ }^{7}$ The EU and its Member States seem still to be trying to import labor but not people - just as the Western European countries did 40 years ago.

The social impacts of this situation for both receiving societies and sending societies are negative. Exploitation of migrant workers and the absence of secure residence status and basic rights for many new residents undermine the rule of law and the welfare state in liberal-democratic societies. Moreover, there is no reason to think that receiving countries will be any more successful in

\footnotetext{
${ }^{7}$ According to a map published in Le Monde Diplomatique in March 2004, 3,300 migrants were drowned trying to cross from Morocco to Spain between 1997 and 2001, while hundreds more died at other crossing places into Europe. In 2006 there were reports that attempts to close off the shortest routes between Africa and Europe had led to even more hazardous routes, as smugglers attempted long Atlantic voyages with canoe-like open boats (pirogues) from Mauritania and even Senegal to the Canary Islands. More than 1,000 migrants were thought to have already drowned in this way. Smugglers charge up to $\$ 550$ per person (Guardian, March 23, 2006).
} 
preventing unplanned settlement of ostensibly temporary migrants than in the past. Whether the new members of society come as undocumented workers or as legal guestworkers, they are likely to experience processes of discrimination and social exclusion. This may well have similar outcomes to past experience in terms of divided societies and social conflict. As for sending countries, the continuation of existing power imbalances and lack of cooperative governance makes it difficult to achieve the potential development benefits of migration, and may lead to major political and social strains.

There has been much discussion about possible alternatives to current migration policies. Although there is no space for detail here, two main approaches may be mentioned: ${ }^{8}$

The first alternative questions whether highly developed countries really do "need" large numbers of lower-skilled workers. The argument is that such labor demand is socially constructed by the poor wages, conditions, and social status accorded such occupations as agricultural laborers, building workers, hospital cleaners, and catering staff. If the conditions and status of such jobs were substantially improved, local workers might be more willing to take them; marginal employers might go out of business; and there would be incentives to improve productivity in these sectors through more investment in laborsaving technologies. Eliminating low-skilled work and upgrading its social status would depend on strict labor market regulation to enforce minimum wages and conditions. This would undercut TMWPs that restrict workers' labor market mobility, residence duration, and human rights. If migrant workers are required, they should have the right to change jobs, bring in families, and stay permanently if they want to. This could be the basis for circular migration, since many migrants have no desire to stay permanently, as long as the option of return is open to them. Similarly, denying cheap labor to European farmers (who are often large companies rather than struggling individuals) would be beneficial to producers in developing countries. But such steps would contradict powerful economic and political interests.

The second alternative refers to policies to enhance international collaboration and governance in the migration field. The idea is that governments and civil society should work together multilaterally to combat abuse and exploitation of migrants, and to realize mutual benefits for both sending and receiving

${ }^{8}$ A third possibility, "open borders," that is, abolishing all migration control and leaving regulation to market forces, has received some support (for differing reasons) from both neo-classical economists and human rights advocates. However, it does not seem a realistic option at present, and might well do more harm than good (see Castles, 2004:872-873). 
countries. Migration should "work for poverty reduction" (IDC, 2004:4-5) and should "become an integral part of national, regional and global strategies for economic growth, in both the developing and the developed world" (GCIM, 2005:4). These and other reports put forward proposals for maximizing the benefits of international migration, including measures to limit the "brain drain," to prevent smuggling and trafficking, to encourage the flow of remittances, and to enhance the role of diasporas as agents of development. Such reports also call for "flexible systems of temporary and circular migration" (IDC, 2004). The GCIM strongly endorsed TMWPs, but noted the danger that they could create a "second-class category of workers." This could be avoided through appropriate program design and strong enforcement of rules on worker rights and conditions (see above and GCIM, 2005:17-18).

Such multilateral approaches do seem to be the most promising way of meeting labor demand in developed countries, while protecting worker rights and enhancing development benefits. But international collaboration requires two things that have been conspicuously absent in the past. The first is the willingness of receiving country governments to work together with sending country governments to achieve mutually beneficial economic outcomes. Up to now, the main objective of the EU and its Member States seems to have been to impose migration restrictions on sending countries. Cooperation to make migration serve development would mean reducing the profitability of migrant labor for receiving countries (at least in the short run), ${ }^{9}$ which in turn would mean taking on powerful employer groups. A second requirement would be the introduction of effective systems of labor market regulation and finding the fiscal resources to hire the necessary army of labor inspectors. That would mean a fundamental departure from the neo-liberal deregulation agenda, as well as a major change in political rhetoric in order to explain the need for migrant labor to a public made skeptical by years of anti-immigration slogans.

Where do these rather pessimistic conclusions leave us? There are possible alternatives to the current migration order, but they are very difficult to implement due to interest divergences and lack of political will. Yet there are positive trends. The European Commission's analysis of Europe's future labor demand does point to the need for a comprehensive and collaborative approach - even though the Policy Plan does not reflect this very well.

${ }^{9}$ In the long run, integration may actually raise migrant workers' productivity, as they acquire education, training, and work experience. Therefore, in the long run employers could well have an interest in migrant integration, but migration policy decisions seem all too often to be based on short-term factors. 
Thinking on migration and development by important public bodies does show a greater willingness to recognize the positive contribution of migrants and the needs of regions of origin. The GCIM Report is a significant milestone. The GCIM was only an advisory body, and its findings may well be ignored by those who hold political power, yet the fact that a body of this kind was supported by the UN Secretary-General was a significant advance: until recently the UN virtually ignored the issue of global governance of migration.

Perhaps what we are seeing at present is that advances made in migration research and theory in recent decades are now beginning to influence bodies that can translate them into policy advice at both national and global levels. But to actually achieve substantial shifts in policies requires the further step of creating the political will for change. This has yet to happen, and requires the active involvement of citizen groups, civil society organizations, and political actors in both sending and receiving societies. Migration researchers have an important role to play, by providing a comprehensive knowledge-base and critical analysis to inform public opinion, policy formation, and politics.

\section{REFERENCES}

\section{Abella, M. I.}

1995 "Asian Migrant and Contract Workers in the Middle East." In The Cambridge Survey of World Migration. Ed. R. Cohen. Cambridge: Cambridge University Press.

Alkire, S., and L. Chen

2006 “'Medical Exceptionalism' in International Migration: Should Doctors and Nurses be Treated Differently?" In Globalizing Migration Regimes. Ed. K.Tamas and J. Palme. Aldershot: Ashgate. Pp. 100-117.

Amnesty International

2005 Amnesty International Contribution to the Commission Green Paper on an EU Approach to Managing Economic Migration. Brussels: Amnesty International EU Office.

Bundesministerium des Innern

2004 Details of the Immigration Act. Berlin: Bundesministerium des Innern. <http:// www.bmi.bund.de>.

Castles, $S$.

2004 "The Factors that Make and Unmake Migration Policy." International Migration Review 38(3):852-884.

2003 "Migrant Settlement, Transnational Communities and State Strategies in the Asia Pacific Region." In Migration in the Asia Pacific: Population, Settlement and Citizenship Issues. Ed. R. Iredale, C. Hawksley, and S. Castles. Cheltenham and Northampton, MA: Edward Elgar. Pp. 3-26.

1986 “The Guest-Worker in Western Europe: An Obituary." International Migration Review 20(4):761-778. 
and G. Kosack

1973 Immigrant Workers and Class Structure in Western Europe. London: Oxford University Press.

CEC

2005a Communication from the Commission: Policy Plan on Legal Migration. COM(2005)669 final. Brussels: Commission of the European Communities.

2005b Green Paper on an EU Approach to Managing Economic Migration. COM(2004)811 final. Brussels: Commission of the European Communities.

Clarke, J., and J. Salt

2003 "Work Permits and Foreign Labour in the UK: A Statistical Review." Labour Market Trends 111(11):563-574.

Dovlo, D.

2006 "Ghanaian Health Workers on the Causes and Consequences of Migration." In Globalizing Migration Regimes. Ed. K. Tamas and J. Palme. Aldershot: Ashgate. Pp. 118127.

Dustmann, C., and A. C. E. Glitz

2005 Immigration, Jobs and Wages: Evidence and Opinion. London: Centre for Economic Policy Research and Centre for Research and Analysis of Migration.

Düvell, F.

2005 Illegal Immigration in Europe: Beyond Control. Basingstoke: Palgrave/Macmillan.

Findlay, A. M.

1995 "Skilled Transients: The Invisible Phenomenon." In The Cambridge Survey of World Migration. Ed. R. Cohen. Cambridge: Cambridge University Press.

GCIM

2005 Migration in an Interconnected World: New Directions for Action: Report of the Global Commission on International Migration. Geneva: Global Commission on International Migration.

Glover, S. et al.

2001 Migration: An Economic and Social Analysis. RDS Occasional Paper 67. London: Home Office.

Green, S.

2004 The Politics of Exclusion: Institutions and Immigration Policy in Contemporary Germany. Manchester: Manchester University Press.

Home Office

2006 A Points-Based System: Making Migration Work for Britain. Command 6741. London: Home Office.

2005 Accession Monitoring Report May 2004-September 2005. London: Home Office, Department for Work and Pensions, HM Revenue and Customs, and Office of the Deputy Prime Minister.

Hunger, U.

2000 "Temporary Transnational Labour Migration in an Integrating Europe and the Challenge to the German Welfare State." In Immigration and Welfare. Challenging the Borders of the Welfare State. Ed. M. Bommes and A. Geddes. London and New York: Routledge. 
and D. Thränhardt

2001 “Die Berliner Integrationspolitik im Vergleich der Bundesländer.” In Migration und Integration in Berlin. Ed. F. Gesemann. Opladen: Leske und Budrich. Pp. 109-125.

IDC

2004 Migration and Development: How to Make Migration work for Poverty Reduction. HC 79-II. London: House of Commons International Development Committee.

IOM

2003 World Migration 2003: Managing Migration-Challenges and Responses for People on the Move. Geneva: International Organization for Migration.

JCWI

2005 JCWI Submission on the European Commission Green Paper on an EU Approach to Managing Economic Migration. London: Joint Council for the Welfare of Immigrants.

Kindleberger, C. P.

1967 Europe's Postwar Growth - The Role of Labor Supply. Cambridge, MA: Harvard University Press.

King, R., G. Lazaridis, and C. Tsardanidis

2000 Eldorado or Fortress? Migration in Southern Europe. London: Macmillan.

Layton-Henry, Z.

2004 "Britain: From Immigration Control to Migration Management." In Controlling Immigration: A Global Perspective. Ed. W. Cornelius, T. Tsuda, P. L. Martin, and J. F. Hollifield. Stanford, CA: Stanford University Press. Pp. 294-333.

Martin, P. L.

2005 Migrants in the Global Labour Market. GCIM Policy Analysis and Research Programme Papers. Geneva: GCIM. <http://www.gcim.org>.

2004 “The United States: The Continuing Immigration Debate." In Controlling Immigration: A Global Perspective. Ed. W. A. Cornelius, T. Tsuda, P. L. Martin, and J. F. Hollifield. Stanford, CA: Stanford University Press. Pp. 50-85.

Migration Policy Institute

2005 A New Century: Immigration and the US. Migration Information Source Country Profile. Washington, DC: Migration Policy Institute. <http://www.migrationinformation.org/>.

OECD

2005 Trends in International Migration: Annual Report 2004. Paris: OECD.

2004 Trends in International Migration: Annual Report 2003. Paris: OECD.

Office for National Statistics

2005 Control of Immigration: Statistics United Kingdom, 2004. London: National Statistics.

Passel, J. S.

2006 Size and Characteristics of the Unauthorized Migrant Population in the U.S. Estimates Based on the March 2005 Current Population Survey. Pew Hispanic Center Report. Washington, DC: Pew Hispanic Center. <http://pewhispanic.org/reports>.

Plewa, P., and M. J. Miller

2005 "Postwar and Post-Cold War Generations of European Temporary Foreign Worker Policies: Implications from Spain." Migraciones Internacionales 3(2):58-83. 
Reyneri, E.

2003 "Immigration and the Underground Economy in New Receiving South European Countries: Manifold Negative Effects, Manifold Deep-Rooted Causes." International Review of Sociology 13(1):117-143.

2001 Migrants' Involvement in Irregular Employment in the Mediterranean Countries of the European Union. Geneva: International Labour Organization.

Rudolph, $\mathrm{H}$.

1996 "The New Gastarbeiter System in Germany." New Community 22(2):287-300.

Ruhs, M.

2005 The Potential of Temporary Migration Programmes in Future International Migration Policy. GCIM Policy Analysis and Research Programme Papers. Geneva: GCIM. <http:// www.gcim.org>.

Schierup, C.-U., P. Hansen, and S. Castles

2006 Migration, Citizenship and the European Welfare State: A European Dilemma. Oxford: Oxford University Press.

Skeldon, R.

2000 "Trends in International Migration in the Asian and Pacific Region." International Social Science Journal (165):369-382.

Somerville, W.

2006 Success and Failure under Labour: Problems of Priorities and Performance in Migration Policy. Discussion Papers. London: Joint Council for the Welfare of Immigrants.

Straubhaar, T., and K. Zimmermann

1992 Towards a European Migration Policy. London: Centre for Economic Policy Research.

Süssmuth, R.

2001 Zuwanderung gestalten, Integration fördern: Bericht der unabhängigen Kommission "Zuwanderung."Berlin: Bundsesminister des Innern.

Wilpert, C., and S. Laacher

1999 "New Forms of Migration and the Informal Labour Market in Old Receiving Countries: France and Germany." In Migrant Insertion in the Informal Economy, Deviant Behaviour and the Impact on Receiving Societies. Ed. E. Reyneri. Brussels: European Commission. Pp. 39-56. 